\title{
Leucas zeylanica (L.) R. Br. protects ethanol and hydrogen peroxide-induced oxidative stress on hepatic tissue of rats
}

\author{
*Shahdat Hossain, Mijanur Rahman, Nusrat Fatima, Mozammel Haque, Jahirul Islam \\ Laboratory of Alternative Medicine E Behavioral Neurosciences, Department of Biochemistry and Molecular Biology, \\ Jahangirnagar University, Savar, Dhaka-1342, Bangladesh
}

\begin{abstract}
The aim of the study was to evaluate the effect of Leucas zeylanica against oxidative stress on hepatic tissue. Oxidative stress was induced by exposing hepatic tissue to ethanol and Fenton's reagent $\left(\mathrm{H}_{2} \mathrm{O}_{2}+\mathrm{FeSO}_{4}\right)$. The effect of oxidative stress on liver also was evaluated by the determination of alanine aminotransferase (ALT), aspartate aminotransferase (AST) and alkaline phosphatase (ALP) activity and the levels of lipid peroxide (LPO). The antioxidative activity of L. zeylanica was determined by estimating it ability to inhibit the hepatic levels of lipid peroxide (LPO), as indicator of oxidative stress. Concomitantly, the antioxidant phytochemicals such as polyphenols and flavonoids were assessed against pyrogallol and quercetin standards. The ALT and AST activities and the levels of LPO of hepatic tissue were significantly increased by oxidative stress. L. zeylanica pretreatment, however, significantly repressed the oxidative stress on hepatic tissue, as indicated by the decreased activities of ALT and AST enzymes and levels of LPO. Analyses of the phytochemicals revealed that the extract of L. zeylanica contained substantial amounts of polyphenols $(74.32 \pm 4.6 \mu \mathrm{g}$ of pyrogallol equivalent $/ \mathrm{mg}$ ) and flavonoids $(15.69 \pm 2.2 \mu \mathrm{g}$ quercetin equivalent $/ \mathrm{mg}$ of extract). Finally, the results of the present study demonstrated the presence of antioxidant phytochemicals, including polyphenols and flavonoids in L. zeylanica and henceforth conferred protection against ethanol and $\mathrm{H}_{2} \mathrm{O}_{2}$-induced oxidative stress on hepatic tissue.
\end{abstract}

Key Words: Leucas zeylanica, AST, ALT, Polyphenols.

\section{INTRODUCTION}

Oxidative stress is the result of imbalance between the reactive oxygen species (ROS) generation and antioxidant defense capacity of the cell. Excess ROS causes oxidation of cellular proteins, lipids and DNA that ultimately leads to the loss of functionality of the cell (Rahman et al., 2013). Oxidative stress has been implicated to a wide variety of pathological conditions like diabetes, cancer, neurodegenerative diseases, arthritis as well as age-related deterioration of hepatic (Videla et al., 1995) and cardiovascular functions (Heistad et al., 2009). Oxidative stress is one of the major pathogenic events that occur in most of chronic liver disorders (Cesaratto et al., 2004).

The liver is the largest and functionally vital organ of the body that participates crucially in metabolism, synthesis, secretory, excretory and detoxification function (Saladin, 2011). The liver is an important target of the toxicity of drugs, xenobiotics, and oxidative stress because of its unique metabolism and relationship to the gastrointestinal tract (Jaeschke et al., 2002). Over hundred known forms of liver diseases are caused by a variety of factors but viral infection, carcinogenesis, alcohol and drugs are known to be frequently associated with liver disease. Oxidative stress plays a central role in most of chronic liver diseases like hepatitis, alcoholic liver disease, hepatocellular carcinoma and liver cirrhosis (Ha et al., 2010). Experimental researches strongly suggest antioxidant supplement as a promising therapeutic intervention for the prevention and treatment of hepatic disorders (Medina and Moreno-Otero, 2005). Therefore, there is

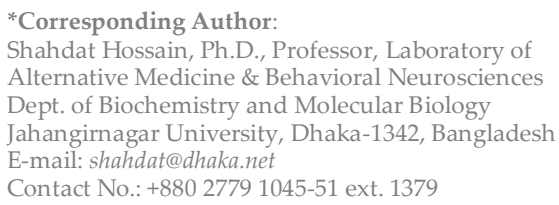

growing interest in the evaluation of possible role of antioxidant phytochemicals capable of protecting or preventing oxidative stress associated with hepatic diseases.

Leucas zeylanica (L.) R. Br., an erect, hispid, annual herb, is commonly known as "Cevlon slitwort". Its local name is "Kusha" and belongs to the Lamiaceae family (Khanam and Hassan, 2005). It is being used in the treatment of burning and urination within the frame of traditional medicine, though adequate evaluation lacks regarding pharmacological activity (Yusuf et al., 2007). Therefore, the aim of the present study was to evaluate the effect of Leucas zeylanica against ethanol and hydrogen peroxide induced oxidative stress on hepatic tissue in concert with its contents of antioxidant phytochemicals.

\section{MATERIALS AND METHODS}

Collection of plant materials and extraction

Wild L. zeylanica was collected from the Manikgong, Dhaka. The plants were identified and authenticated by the Department of Botany, Jahangirnagar University, Savar, Dhaka. The fresh leaves with petioles were then dried in shadow and ground into fine powder using mechanical grinder. Fine plant powder was subjected to the exhausted extraction using $100 \%$ methanol as the extraction solvent. The solvent was evaporated under reduced pressure using a rotary evaporator at $45^{\circ} \mathrm{C}$. The thick residue of the extract was then stored at $4^{\circ} \mathrm{C}$ until further use.

\section{Animals}

Ten Wistar male rats ( 25 weeks of age) of weight $200 \mathrm{~g}$ $220 \mathrm{~g}$ were used in the present study. The rats were housed in an animal house at $25^{\circ} \mathrm{C}$ under $12 \mathrm{~h}$ dark-light cycles (light 8.00-20.00 h; dark 20.00-8.00 h. All the rats were allowed free access to basal diet and tap water. The rats were accustomed to the laboratory for 7 days. 


\section{Preparation of hepatic tissue sample}

The rats were sacrificed under deep anesthesia and the blood was collected in a tube. Whole livers were surgically removed and perfused three times with $50 \mathrm{mM}$ phosphate buffer saline ( $\mathrm{pH}$ 7.4). Liver tissue was then homogenized in phosphate buffer saline $(50 \mathrm{mM}$; pH 7.4) using Polytron tissue homogenizer. Then the homogenate was centrifuged at $600 \mathrm{rpm}$ for 10 minutes to remove the cellular debris. The supernatant was collected, assigned as whole homogenate and used for further study.

\section{Generation of oxidative stress in hepatic tissue}

The hepatic whole tissue homogenate was exposed to ethanol and Fenton's reagent to induce for oxidative stress.

Preparation of ethanol-treated hepatic tissue

$400 \mu$ l of liver whole homogenate was incubated without (control) or with (test) L. zeylanica extract $(1000 \mu \mathrm{g} / \mathrm{ml})$ for 2 hours at $37^{\circ} \mathrm{C}$ with intermittent shaking. The samples were centrifuged at $2000 \mathrm{rpm}$ and the supernatants were discarded. The remaining tissue was washed with phosphate buffer saline (50mM; $\mathrm{pH} 7.4)$ for three times and reconstituted into $300 \mu \mathrm{l}$ of phosphate buffer saline (50mM; pH 7.4). Then, both of the control and test samples were exposed to ethanol $(50 \mu \mathrm{l} ; 65 \%)$ for 1 hour at $37^{\circ} \mathrm{C}$. Finally, the samples were centrifuged at $4000 \mathrm{rpm}$ for 10 minutes. The supernatants were then collected and subjected to enzymatic assay.

Preparation of hydrogen peroxide $\left(\mathrm{H}_{2} \mathrm{O}_{2}\right)$-treated hepatic tissue $400 \mu \mathrm{l}$ of liver homogenate was incubated without (control) or with (test) L. zeylanica extract $(1000 \mu \mathrm{g} / \mathrm{ml})$ for 2 hours at $37^{\circ} \mathrm{C}$ with intermittent shaking. The samples were centrifuged at $2000 \mathrm{rpm}$ and the supernatants were discarded. The remaining tissue was washed with phosphate buffer saline $(50 \mathrm{mM}$; $\mathrm{pH} 7.4)$ for three times and reconstituted into $300 \mu \mathrm{l}$ of phosphate buffer saline (50mM; pH 7.4). Then, both of the control and test samples were exposed to Fenton's reagent $\left(\mathrm{FeSO}_{4}+\mathrm{H}_{2} \mathrm{O}_{2}\right)$ for 1 hour at $37^{\circ} \mathrm{C}$. Finally, the samples were centrifuged at $4000 \mathrm{rpm}$ for 10 minutes. The supernatants were then collected and subjected to enzymatic assay.

\section{Enzymatic assay}

Alanine aminotransferase (ALT), aspartate aminotransferase (AST) and alkaline phosphatase (ALP) activity assay was performed as a measure of extent of oxidative stress on hepatic tissue by colorimetric methods using autoanalyzer (Siemens Dimension RXL, Healthcare Diagnostics, USA). The results of enzymatic activity were expressed as $\mathrm{U} / \mathrm{L} / \mathrm{mg}$ of protein while total protein of hepatic tissue homogenate was estimated by the Lowry method (Lowry et al., 1951).

\section{In vitro lipid peroxide (LPO) assay}

Levels of hepatic lipid peroxide (LPO) were estimated according to the thiobarbituric acid reactive substances test. Fenton's reagent $\left[\mathrm{H}_{2} \mathrm{O}_{2}(45 \mathrm{mM})+\mathrm{FeSO}_{4}(2 \mathrm{mM})\right]$ (final concentration) were used to induce in vitro oxidative stress on the hepatic tissue without (control) or with (test) L. zeylanica extract $(1000 \mu \mathrm{g} / \mathrm{ml})$. Malondialdehyde content in the homogenates was determined by previously described (Rahman et al., 2012) method as an indicator of oxidative stress. Lipid peroxidation of hepatic tissue was calculated as $\mathrm{nmol} / \mathrm{mg}$ of protein and total protein in the tissue homogenate was estimated by the Lowry method (Lowry et al., 1951).
Table 1: Effect of L. zeylanica extract on enzymes of ethanoltreated hepatic tissue

\begin{tabular}{lllll}
\hline Parameters & CON & LTT & ETT & PET \\
\hline $\begin{array}{l}\text { ALT (U/L/mg } \\
\text { of proteins) }\end{array}$ & $1.15 \pm 0.03^{\mathrm{a}}$ & $1.05 \pm 0.03^{\mathrm{a}}$ & $3.39 \pm 0.04^{\mathrm{b}}$ & $2.90 \pm 0.03^{\mathrm{c}}$ \\
$\begin{array}{l}\mathrm{AST}(\mathrm{U} / \mathrm{L} / \mathrm{mg} \\
\text { of proteins) }\end{array}$ & $2.39 \pm 0.01^{\mathrm{a}}$ & $2.21 \pm 0.04^{\mathrm{a}}$ & $4.96 \pm 0.05^{\mathrm{b}}$ & $4.57 \pm 0.05^{\mathrm{c}}$ \\
$\begin{array}{l}\mathrm{ALP}(\mathrm{U} / \mathrm{L} / \mathrm{mg} \\
\text { of proteins) }\end{array}$ & $0.048 \pm 0.01^{\mathrm{a}}$ & $0.045 \pm 0.01^{\mathrm{a}}$ & $0.13 \pm 0.01^{\mathrm{a}}$ & $0.11 \pm 0.01^{\mathrm{a}}$ \\
\hline
\end{tabular}

Here, $\mathrm{CON}=$ Control, $\mathrm{LTT}=$ L. zeylanica extract-treated hepatic tissue, ETT= Ethanol-treated hepatic tissue, PET= Ethanol-treated hepatic tissue preincubated with L. zeylanica extract. Data were expressed as mean \pm SEM (Standard error of mean; $n=5$ ). The values in the same row with different superscripts are significantly $(\mathrm{P}<0.05)$ different. Data were analyzed by one-way ANOVA, followed by Tukey's least square differences test for post hoc comparisons.

\section{Estimation of antioxidant phytochemicals}

Total polyphenols content of extracts was determined following Amin et al., (2006) using pyrogallol as standard. The concentration of total phenolic compounds in extracts was determined as pyrogallol equivalents ( $\mu \mathrm{g}$ of $\mathrm{PE} / \mathrm{mg}$ of extract). The total flavonoids content of the extract was estimated following aluminum chloride colorimetric assay described by Chang et al. (2001). Quercetin was used as standard. The concentration of total flavonoid in the extract was determined as quercetin equivalents $(\mu \mathrm{g}$ of $\mathrm{QE} / \mathrm{mg}$ of extract).

\section{Statistical analyses}

The results were expressed as mean \pm SEM (Standard error of mean). The statistical programs used were StatView ${ }^{\circledR}$ 4.01 (MindVision Software, Abacus Concepts, Inc., Berkeley, CA, USA) and GraphPad Prism ${ }^{\circledR}$ (version 4.00; GraphPad Software Inc., San Diego, CA, USA). Intergroup variation was analyzed by one way ANOVA followed by Tukey's least square differences test for post hoc comparisons. A level of $P<0.05$ was considered statistically significant.

\section{RESULTS}

Effect of L. zeylanica extract on ethanol-treated hepatic tissue

In the present study, incubation of hepatic tissue homogenate with ethanol significantly $(\mathrm{P}<0.05)$ increased the levels of ALT and AST but not ALP. Incubation of hepatic tissue homogenate alone with extract did not increase the enzyme activity. Pre-incubation of hepatic tissue with the extract, however, significantly reduced $(\mathrm{P}<0.05)$ the levels of ALT and AST in ethanol-treated tissue homogenates, when compared with those of the untreated control tissue homogenates (Table 1).

\section{Effect of L. zeylanica extract on $\mathrm{H}_{2} \mathrm{O}_{2}$-treated hepatic tissue}

The levels of ALT and AST were not increased as a result of incubation of hepatic tissue homogenate with extract alone. But, exposure of hepatic tissue to hydrogen peroxide of Fenton's reagent significantly $(\mathrm{P}<0.05)$ increased the levels of ALT and AST but not ALP levels. Pre-incubation of hepatic tissue with the extract significantly reduced $(\mathrm{P}<0.05)$ the levels of ALT and AST in Fenton's reagent treated tissue homogenates, when compared with those of the untreated control tissue homogenates (Table 2). 
Table 2: Effect of L. zeylanica extract on enzyme activities of $\mathrm{H}_{2} \mathrm{O}_{2}$-treated hepatic tissue

\begin{tabular}{lllll}
\hline Parameters & CON & LTT & HTT & PHT \\
\hline $\begin{array}{l}\text { ALT (U/L/mg } \\
\text { of proteins) }\end{array}$ & $1.13 \pm 0.01^{\mathrm{a}}$ & $0.94 \pm 0.01^{\mathrm{a}}$ & $2.27 \pm 0.04^{\mathrm{b}}$ & $2.04 \pm 0.01^{\mathrm{c}}$ \\
$\begin{array}{l}\mathrm{AST}(\mathrm{U} / \mathrm{L} / \mathrm{mg} \\
\text { of proteins) }\end{array}$ & $2.31 \pm 0.04^{\mathrm{a}}$ & $2.18 \pm 0.02^{\mathrm{a}}$ & $4.47 \pm 0.03^{\mathrm{b}}$ & $4.03 \pm 0.03^{\mathrm{c}}$ \\
$\begin{array}{l}\mathrm{ALP}(\mathrm{U} / \mathrm{L} / \mathrm{mg} \\
\text { of proteins) }\end{array}$ & $0.05 \pm 0.01^{\mathrm{a}}$ & $0.03 \pm 0.01^{\mathrm{a}}$ & $0.13 \pm 0.01^{\mathrm{a}}$ & $0.1 \pm 0.01^{\mathrm{a}}$ \\
\hline
\end{tabular}

Here, $\mathrm{CON}=$ Control, $\mathrm{LTT}=$ L. zeylanica extract treated hepatic tissue, HTT= Hydrogen peroxide treated hepatic tissue, $\mathrm{PHT}=$ Hydrogen peroxide treated hepatic tissue preincubated with L. zeylanica extract. Data were expressed as mean \pm SEM (Standard error of mean; $n=5$ ). The values in the same row with different superscripts are significantly different. Data were analyzed by one-way ANOVA, followed by Tukey's least square differences test for post hoc comparisons.

\section{Effect of L. zeylanica extract on lipid peroxidation}

Fenton's reagent significantly induced the oxidative stress (OS) on the hepatic tissues, as indicated by the increased levels of LPO. Co-incubation of hepatic tissue homogenate with extract significantly decreased the LPO levels (Figure 1). Addition of L. zeylanica extract protected the hepatic tissues against Fenton's reagent-instigated lipid peroxidation.

\section{In vitro antioxidant activity}

Antioxidant phytoconstituents estimated in the present study include polyphenols and flavonoids. The polyphenols content of $100 \%$ methanol extract of L. zeylanica was $74.32 \pm 4.6 \mu \mathrm{g}$ of $\mathrm{PE} / \mathrm{mg}$ of extract while the flavonoids content was $15.69 \pm 2.2 \mathrm{QE} / \mathrm{mg}$ of extract.

\section{DISCUSSION}

The oxidative stress has recently been recognized as a fundamental factor in the pathological change associated with both alcoholic and nonalcoholic liver diseases. (Tanikawa and Torimura, 2006). In the present study, we investigated whether L. zeylanica extract could protect the hepatic tissue against ethanol and hydrogen peroxideinduced oxidative stress.

We used ethanol and Fenton's reagent to induce oxidative stress on the hepatic tissue while performed ALT, AST and ALP activity to assess the consequence of oxidative stress. Both of ethanol and Fenton's reagent treatment raised the levels of ALT $(\sim 3$ times $)$ and AST $(\sim 2$ times) but not ALP. Hepatic tissue preincubated with $L$. zeylanica extract exhibited a protective effect against such oxidative stress, as indicated by the significant reduced levels of ALT ( 13-15\%) and AST ( 8-10\%) upon ethanol and hydrogen peroxide exposure. Thus, the result of the present study demonstrate that both the hydrogen peroxide and ethanol clearly instigated the oxidative stress in the hepatic tissues and consequently mimicked in vivo hepatotoxicity with respect to damage to the structural integrity of the liver.

Ethanol promotes oxidative stress, both by increasing ROS formation and by decreasing cellular defense mechanisms and these effects of ethanol are prominent in the liver (Hoek et al., 2002). Being small water soluble molecule, hydrogen peroxide can cross cell membranes rapidly. Once inside the cell, $\mathrm{H}_{2} \mathrm{O}_{2}$ could react with $\mathrm{Fe}^{2+}$, and possibly $\mathrm{Cu}^{2+}$ ions to form hydroxyl radical while liver is a metal rich organ (Halliwell, 1993). ALT is mainly located in the cytoplasm whereas AST is evenly distributed between cytoplasm and mitochondria. In severe acute liver damage, ALT and AST levels are almost equally

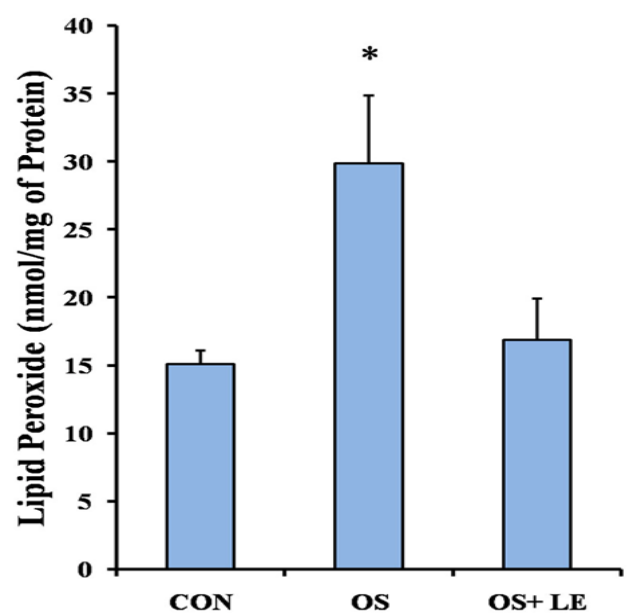

Figure 1: Effect of L. zeylanica extract on lipid peroxidation. The bars represent the mean \pm SEM $(n=3)$. CON $=$ Control; OS $=$ Fenton's reagent-induced oxidative stress on hepatic tissue homogenate; OS + LE = Fenton's reagent-induced oxidative stress on hepatic tissue homogenate plus L. zeylanica extract. Data were analyzed by One-way ANOVA was followed by Tukey's least square differences test. *Bars with different notations are significantly different at $\mathrm{P}<0.05$.

elevated, indicating that both cellular and mitochondrial membrane has been damaged (Kaplan and Szabo, 1983). We infer therefore that the extract might have disseminated at least to the cytoplasm level to confer hepatoprotective effect. With above findings in hand, we also evaluated a similar protective effect of extract in Fenton's reagent-induced oxidative stress on hepatic tissue. The treatment with Fenton's reagent significantly increased the lipid peroxide levels of hepatic tissue. Cotreatment of hepatic tissue with extract significantly decreased $(\sim 37.5 \%)$ the levels of lipid peroxide. During Fenton's reagents-induced lipid peroxidation, iron salts are thought to react with $\mathrm{H}_{2} \mathrm{O}_{2}$ to produce hydroxyl radicals $\left({ }^{\circ} \mathrm{OH}\right)$ which causes peroxidation reaction of lipids and the formation of malonaldehyde (MDA) (Duh, 1998). The $\bullet \mathrm{OH}$ radical is the most potent lone pair reactive oxygen species that cause a severe detrimental change in membrane structure leading to an increased permeability of the membrane and damage to biological component molecules (Beer et al., 2002). Therefore, the result of the Fenton's reagent-induced oxidative stress supported our previous proposition as well as denoted the probable presence of antioxidant phytoconstituents in the extract. In the present study, we estimated polyphenols and flavonoids content of the extract. The polyphenols content of L. zeylanica extract was $74.32 \pm 4.6$ $\mu \mathrm{g}$ of $\mathrm{PE} / \mathrm{mg}$ of extract while the flavonoids content was $15.69 \pm 2.2 \mu \mathrm{g} \mathrm{QE} / \mathrm{mg}$ of extract. Thus, the presence of appreciable amount of polyphenol and flavonoids strengthen our propositions further.

\section{CONCLUSION}

We are first to report the in vitro hepatoprotective effect of L. zeylanica against ethanol and Fenton's reagent-induced oxidative stress. The present study also demonstrates that hepatoprotective effect of the extract is closely associated with antioxidative activity. However, further studies are suggested to explore the effect of the extract on in vivo oral administration to animal model as well as elaborate mechanism and disease specific therapeutic intervention. 


\section{ACKNOWLEDGEMENT}

This work was supported, in part, by a Grant-in-Aid from the World Bank-University Grant Commission-aided subproject (CP-358), 'Establishment of $\mathrm{PhD}$ program in the Dept. of Biochemistry and Molecular Biology, Jahangirnagar University, Savar, Dhaka, Bangladesh'.

\section{REFERENCES}

Cesaratto, L., Vascotto, C., Calligaris, S. and Tell, G. (2004). The importance of redox state in liver damage. Annals of Hepatology. 3(3): 86-92. PMID: 15505592

de Beer, D., Joubert, E., Gelderblom, W. C. A. and Manley, M. (2002). Phenolic compound: a review of their possible role as in vivo antioxidants of wine. South African Journal for Enology and Viticulture. 23(2): 48-61.

Duh, P. D. (1998). Antioxidant activity of burdock (Arctium lappa Linn): It's scavenging effect on free radical and active oxygen. Journal of the American Oil Chemists' Society. 75(4): 455-461. [DOI]

Ha, H. L., Shin, H. J., Feitelson, M. A. and Yu, D.Y. (2010). Oxidative stress and antioxidants in hepatic pathogenesis. World Journal of Gastroenterology. 16(48): 6035-6043. [DOI]

Halliwell, B. and Gutteridge, J. M. C. (1989). Free Radicals in Biology and Medicine (3rd ed., pp. 446-493). Oxford, Oxford University Press.

Heistad, D. D., Wakisaka, Y., Miller, J., Chu, Y. and Pena-Silva, R. (2009). Novel aspects of oxidative stress in cardiovascular diseases. Circulation Journal. 73: 201-207. [DOI]

Hoek, J. B., Cahill, A. and Pastorino, J. G. (2002). Alcohol and mitochondria: a dysfunctional relationship. Gastroenterology. 122(7): 2049-2063. [DOI]

Jaeschke, H., Gores, G. J., Cederbaum, A. I., Hinson, J. A., Pessayre, D. and Lemasters, J. J. (2002). Mechanisms of Hepatotoxicity. Toxicological Sciences. 65: 166-176. [DOI]
Kaplan, A. and Szabo, L. L. (1983). Clinical chemistry: interpretation and techniques (2nd ed., pp. 173-242). Philadelphia, Lea and Febiger.

Khanam, M. and Hassan, M. A. (2005). A critical study of the genus Leuca R. Br. (Lamiaceae) from Bangladesh. Bangladesh journal of Plant Taxonomy. 12(1): 1-10. [DOI]

Lowry, O. H., Rosebrough, N. J., Farr, A. L. and Randall, R. J. (1951) Protein measurement with the Folin-Phenol reagents. The Journal of Biological Chemistry. 193: 265-275.

Medina, J. and Moreno-Otero, R. (2005). Pathophysiological basis for antioxidant therapy in chronic liver disease. Drugs. 65(17): 2445-2461. [DOI] PMID:16296871

Rahman, M., Hossain, S., Rahaman, A., Fatima, N., Nahar, T., Uddin, B and Basunia, M. A. (2013). Antioxidant activity of Centella asiatica (linn.) urban: impact of extraction solvent polarity. Journal of Pharmacognosy and Phytochemistry. 1(6) 27-32.

Saladin, K. S. (2011). Anatomy \& Physiology: The Unity of Form and Function (6th ed., pp. 887-925). USA, The McGraw-Hill Companies.

Tanikawa, K. and Torimura, T. (2006). Studies on oxidative stress in live diseases: important future trends in liver research. Medical Molecular Morphology. 39(1): 22-27. [DOI] PMID: 16575511

Videla, L. A., Fernandez, V., Carrion, Y., Azzalis, L. A., Bainy, A. C. D. and Junqueira, V. B. C. (1995). Biochemical mechanisms in hepatotoxicity oxidative stress induced by xenobiotics and hormonal changes. Ciencia e Cultura. 47:385-384

Yusuf, M., Wahab, M. A., Yousuf, M., Chowdhury, J. U. and Begum, J. (2007). Some tribal medicinal plants of Chittagong hill tracts, Bangladesh. Bangladesh journal of Plant Taxonomy. 14(2): 117-128. [DOI] 